\title{
Space and Nonspace: The Future of Mobility in Global Capitalism
}

Chad Andrews

A graphic representation of data abstracted from the banks of every computer in the human system. Unthinkable complexity. Lines of light ranged in the nonspace of the mind, clusters and constellations of data. Like city lights, receding... ${ }^{1}$ William Gibson, Neuromancer

Today, after over twenty years since the publication of Neuromancer, ${ }^{2}$ it is impossible to ignore the fact that Gibson's description of cyberspace has become disappointingly banal. Network technologies have accelerated to a level of unprecedented sophistication, and have over the last two decades bridged the gap between cyberpunk's central extrapolation - called "cyberspace," or "the matrix," or "the metaverse," depending on taste - and our contemporary technological landscape. In this case, science fiction has lost one of its defining characteristics, its focus on futurity and difference, and betrayed its inability to imagine anything other than the here and now. ${ }^{3}$

Of course, the concept of "jacking in" to a network system, of downloading one's subjectivity into a virtual space, remains thoroughly science fictional. But it can be argued that this is really only a matter of user interface, and that in Neuromancer, the idea operates as a tantalizing, hallucinogenic fiction to satisfy the imaginations of readers. When we proceed with this in mind, then, it is hardly a leap to conceptualize cyberspace as our contemporary model of communication, to refer to the internet as a kind of cyberspace, and to think, in broader terms, of modern technoculture as a partial realization of Gibson's vision in Neuromancer. This is perhaps the main reason Gibson no longer writes science fiction - the future, at least as he conceived of it, is already here. ${ }^{4}$

But what does it mean to say that Neuromancer's prophetic vision of technology has been realized? And if it has been realized, if the fiction has transmogrified into reality, what is the point of going back to the fiction, to cyberpunk and its various authors? Over the course of this paper I hope to make a case for just that, for taking another look at the cyberpunk fictions (particularly Neuromancer) that emerged in the 80s. But this will not amount to overemphasizing their extrapolative dimensions (I think this has been covered, here and elsewhere) - instead, Neuromancer (and its central novum, cyberspace) can be 
used as a prism through which we can come to terms with various social and political realities; specifically, the peculiar tension between what I term space and, borrowing from Gibson, nonspace. The freedom of mobility we experience in the latter - that is, through our central communication technology, the internet - highlights the kind of immobility we experience in actual space.

\section{Mobility in Nonspace}

The interpretations of Gibson's cyberspace are as numerous as they are diverse. As Lisa Swanstrom explains, Michael Heim's “The Erotic Ontology of Cyberspace” and Robert Markley's “Boundaries: Mathematics, Alienation, and the Metaphysics of Cyberspace" both criticize the concept, reading it as an affirmation of Platonic idealism, one that "undermines the importance of the real, physical world and diminishes the importance of the body." In her influential "Cyberpunk: Preparing the Ground for Revolution or Keeping the Boys Satisfied?" Nicola Nixon sees it as a proving ground for male dominance, one that involves "jacking in" to the matrix and "penetrating" anti-virus subroutines (a kind of "metaphoric hymeneal membrane") - the matrix is therefore softened and feminized, and the act of hacking tantamount to rape. ${ }^{6}$ According to Thomas Bredehoft's description in "The Gibson Continuum: Cyberspace and Gibson's Mervyn Kihn Stories," it is nothing more than an amalgamation of 30s-era futurism and 60s-era drug culture. ${ }^{7}$

It is unusually straightforward, then, to focus on cyberspace as an extrapolative concept, and to highlight its banal nature in the context of modern communication technologies. Nevertheless, the interpretation of cyberspace as contemporary technology seems justified: when you remove its hallucinatory aspect and the literal act of "plugging in," all that is left is the "unthinkable complexity" and the "clusters and constellations of data" - in other words, experiences found on the internet on a daily basis (in Neuromancer, of course, Gibson's electric prose makes everything seem otherworldly).

Still, the reduction of cyberspace to the commonplace has certain benefits. It allows us to read Gibson's use of the concept in direct correlation to our own experiences. When the novel's central protagonist, Case (a low-life punk and "console cowboy"), euphorically dives into cyberspace, he experiences infinite, unhampered mobility, a sense of 
limitlessness, and a horizon of untapped potentialities. He experiences, in other words, a freedom of movement through a kind of ephemeral nonspace.

Through our own online "movements" through data, we achieve a similar kind of mobility - a freedom to transgress boundaries, to nomadically wander, or to partake in what Lisa Swanstrom has characterized as acts of "connection, penetration, and rupture." 8 Despite the legitimate claims that the internet is dominated by centralized, hierarchical structures, and that corporate entities govern what would otherwise be an open-ended system, it is difficult to ignore the fact that we move through these structures in a relatively unrestricted manner.

Case's first dive into cyberspace in Neuromancer provides a similar picture of unrestricted movement. After attaching a set of "trodes," he closes his eyes and:

fluid neon origami trick, the unfolding of his distanceless home, his country, transparent 3D chessboard extending to infinity. Inner eye opening to the stepped scarlet pyramid of the Eastern Seaboard Fission Authority burning beyond the green cubes of Mitsubishi Bank of America, and high and very far away he saw the spiral arms of military systems, forever beyond his reach. ${ }^{9}$

The matrix Case observes is one ruled by nodes of power. He sees a neon corporate cityscape dominated by the "scarlet pyramid of the Eastern Seaboard Fission Authority" and the "green cubes of Mitsubishi Bank of America." Nevertheless, he is able to navigate freely around them. He may be unable to penetrate to their cores, but this restriction is negligible in comparison to the unhindered mobility and overall freedom he experiences in the net.

The arrival of this kind of Gibsonian freedom points towards a series of political potentialities (new forms of resistance and subjectivities, for instance), but it also highlights an inverse situation in the material world. We may have become prosthetic gods through our use of communication technologies, but we remain restrained with regards to our movements through actual space.

\section{Immobility in Space}

As outlined, Neuromancer certainly illustrates the freedom of movement that modern technology offers us, even if this movement is only virtual. As will be discussed, 
however, the text also can be seen to foreground the constraints we experience in the material realm - constraints, I would like to argue, that are likewise the topic of Antonio Negri's theoretical investigations. Negri offers a model of a contemporary capitalism that has expanded beyond the boundaries of the workday, where it no longer has an outside, but has invaded every level of human life and existence. As will be shown, his work provides the kind of conceptual tools (specifically, the concepts of formal and real subsumption) that, when read alongside Gibson's use of cyberspace, provide us with an understanding of the material immobility we experience under globalized capitalism. His work even provides - if only tenuously - potential avenues for escape and flight (avenues ignored by Gibson in Neuromancer). In what follows, then, I hope to argue that by reading Gibson alongside Negri, we can begin to conceive of the complex nature of modern technoculture under capitalism (specifically, what I call the paradox of mobility in global capitalism), and, additionally, develop an understanding of the restrictions and freedoms that follow.

Along with many of the theorists active during the tumultuous $60 \mathrm{~s}$ and $70 \mathrm{~s}$ in Italy, Negri defines the new form of capitalist control as a continuation and extension of what Marx termed "formal subsumption." According to Negri, Marx used the term to name processes whereby capital incorporates under its own relations of production laboring practices that originated outside its domain. The processes of formal subsumption are thus intrinsically related to the extension of the domain of capitalist production and capitalist markets. ${ }^{10}$

If we conceptualize capitalism as an unstoppable force moving in every direction, vampiristically consuming all forms of labour for its own survival, we come close to an understanding of what Marx meant - and this is certainly the picture of $19^{\text {th }}$ century capitalism that Marx witnessed, an unstoppable system that had not yet reached the level of global domination. But our contemporary form of capitalism has reached the level of global supremacy (a reality evidenced by the modern capitalist's triumphalism and near-religious belief that the system's ubiquity represents the end of history). For Negri, the fact that capitalism has conquered the globe means that it can no longer incorporate anything that is "outside" - there is no outside. Instead, we have witnessed the transition from formal subsumption - the incorporation of external labour - to real subsumption. As Negri puts it, 
The processes of the real subsumption of labor under capital do not rely on the outside and do not involve the same processes of expansion. Through the real subsumption, the integration of labor into capital becomes more intensive than extensive and society is ever more completely fashioned by capital. ${ }^{11}$

If our picture of Marx's capitalism was one of a system vampiristically feeding on the outside, sustaining itself through external incorporation, our picture of contemporary global or late capitalism is one of cannibalism, of self-sacrifice and intensification. With nowhere left to go, expansion must paradoxically move inwards. Thus, we are left with what Matteo Mandarini, in his introduction to Time for Revolution, describes as a process whereby "Capital subsumes the whole of social life" ${ }^{12}$ In this way, Negri provides an explanation for a wide range of disturbing phenomena: the extension of the workday and the disappearance of leisure time, the commodification of life in all its forms (Negri points to the various copyrights of genetic sequences), the transformation of the university into a training ground for young capitalists, and, perhaps most importantly, the pervasive sense of conflict and competition that dominates the majority of our social transactions.

Negri's analysis of capitalist development allows us to see that things are quite similar in much of Gibson's early work; in fact, we find real subsumption pushed to even more extreme limits. In Neuromancer, for instance, Case is less a heroic, autonomous agent of his own destiny, and more a corporate puppet. He eventually realizes that his entire mission has been the result of a conflict between an ancient corporation/family, the TessierAshpools, and the sibling AIs they have been keeping under their control. Society in Neuromancer is dominated by these infinitely complex corporations, and they exert power without regulation or restriction. At the novel's conclusion, Case is confronted by Wintermute, the newly-freed AI construct, who has evolved to a new level of intelligence "I'm the sum total of the works, the whole show," it tells Case. Hoping for some sense of purpose or meaning, a chance that things may have changed or improved, Case asks, "So what's the score? How are things different? You running the world now? You God?" Wintermute's response is telling: "Things aren't different. Things are things."

So not only is everyday life lived under the logic of corporate domination and command - capitalism without restraint, and real subsumption at its apex - but there is no chance for escape or flight. Things do not get better. Things are merely things. 
The future that Neuromancer paints is therefore one of unrestricted, totalizing capitalism, one of the end of history. It becomes clear why Case's only concern is to flee the flesh, to escape the restrictions of "meat" and get lost in the endless virtual landscapes of the net. In a society with no life outside capitalism, where one is inert, immobile, and unable to flee, the only rational option is to pursue a kind of technological independence and self-determination in the "nonspace of the mind."

Keeping Negri's picture of real subsumption in mind, then, we can see that Gibson's cyberpunk (and in particular, Neuromancer) illustrates a fundamental paradox at the core of contemporary life under capitalist command. While our technological sophistication offers limitless mobility in nonspace (the console cowboy's fever dream), we find restraints, unchecked mechanisms of power, and widespread immobility in our daily lives. Case's disillusionment and dissatisfaction with his material existence is therefore hardly idiosyncratic - instead, it can be interpreted as an underlying condition of modern life. While Neuromancer provides us with a clear picture of technological mobility (cyberspace), we can see that Negri's insights are required to foreground the concept of material immobility, of unchecked capitalism invading every level of existence. An understanding of the paradox, then, is the result of this combined reading: Neuromancer through the prism or optic of Negrian political theory.

\section{The Future of Mobility in Global Capitalism}

In the aforementioned "Cyberpunk: Preparing the Ground for Revolution or Keeping the Boys Satisfied?", Nixon's scathing critique of the cyberpunk movement, the claim is made that cyberpunk does not represent the kind of revolutionary project it initially claimed to be. When thinking of the subgenre in very broad, even meta-diegetic terms, this is certainly the case. Many of Bruce Sterling's bombastic claims in his introduction to Mirrorshades (the cyberpunk manifesto that essentially "launched" the sub-genre) ignore the groundbreaking work that was done a decade earlier. But at the same time, there is no need to try to locate this revolutionary potential in specific cyberpunk texts, including Neuromancer. The novel is devoid of the kind of social critique Nixon claims the subgenre strives for - not in the sense that the critique is there but false, but in the sense that politics and social critique were never elements of Gibson's early work. Indeed, with Neuromancer 
we find a text that is thoroughly, unquestioningly apolitical. If there is a project, then, it is not revolutionary or transformative, but rather observational and detached, less political and more sociological. As Veronica Hollinger has described it, the text is "phenomenological" - its central concern is our day-to-day experience of technoculture and the confusion and displacement that follows.

As I have stated, Gibson's cyberpunk can act as a conceptual apparatus through which one can investigate contemporary sociopolitical phenomena, and when read alongside Negri's analysis of late capitalism, we come to a clearer understanding of the central paradox I have outlined - that modern life is simultaneously defined by immobility and mobility. As shown, Neuromancer's central technology, cyberspace, aids us in thinking about the nature of our own network technologies, along with the freedoms and dangers they present. At the same time, the street-level experiences of the characters under the sway of mega-corporations are analogous to our contemporary experience of real subsumption (as outlined by Negri), of a twisted system of production forced to cannibalistically feed on itself. This is the primary observation of Neuromancer, that life is simultaneously characterized by technological freedom and material constraint.

If we want to go beyond this level of simple observation, though, and proceed to some understanding of praxis and potential change, a kind of selective abandonment or intentional misreading of Neuromancer is necessary. The text may assist an understanding of contemporary life, but additional tools are required for a way forward.

Unfortunately, mapping that potential is outside the limitations of this paper, and it will have to suffice to make some small suggestions. Interestingly, while Gibson portrays cyberspace as pure escapism - a momentary relief from suffocating restrictions in the material world - Negri sees the advancement of network technologies as providing new opportunities for social cohesion and subversive resistance. In Empire, he goes so far as to insist on ever-more complex forms of "hybridization and mutation," a kind of posthuman abandonment of bodies that are susceptible to control - what he terms a large-scale "anthropological exodus." 14 According to him, "We certainly do need to change our bodies and ourselves, and in perhaps a much more radical way than the cyberpunk authors imagine." 15 Thinking of political change in relation to Neuromancer, then, involves this radical misreading - that technology (cyberspace included) offers not just escape, but the 
potential for a future where things are not just things, but something radically, monstrously different. 


\section{Notes}

${ }^{1}$ William Gibson, Neuromancer (New York: Ace Books, 1984), p. 51.

${ }^{2}$ Neuromancer, William Gibson's first novel published in 1984, was a breakthrough hit both critically and commercially, essentially launching the sub-genre of cyberpunk literature in science fiction, a form that would become popular in film and television over the next two decades. The text became famous for, among other things, conceptualizing the internet before it existed, and coining the term "cyberspace," Gibson's own unique invention.

${ }^{3}$ The phenomenon is hardly new, and many critics have been pointing to sf's inability to imagine the future for decades. See Frederic Jameson's various statements regarding sf (in Postmodernism, or, The Cultural Logic of Late Capitalism and elsewhere), or, for an analysis of cyberpunk specifically, Istvan Csicsery-Ronay, Jr.'s "Futuristic Flu, or, The Revenge of The Future," collected in Fiction 2000: Cyberpunk and the Future of Narrative.

${ }^{4}$ See Gibson's newest trilogy, comprised of Pattern Recognition, Spook Country, and Zero History, all set in the same contemporary reality.

${ }^{5}$ Lisa Swanstrom, "Capsules and Nodes and Ruptures and Flows: Circulating Subjectivity in Neal Stephenson's Snow Crash,” Science Fiction Studies 110 (2010), p. 54.

${ }^{6}$ Nicola Nixon, "Cyberpunk: Preparing the Ground for Revolution or Keeping the Boys Satisfied?" Science Fiction Studies 57 (1992). Available at www.depauw.edu/sfs (accessed 25 March 2009).

${ }^{7}$ Thomas A. Bredehoft, "The Gibson Continuum: Cyberspace and Gibson's Mervyn Kihn Stories," Science Fiction Studies 66 (1995). Available at www.depauw.edu/sfs (accessed 25 March 2009).

${ }^{8}$ Swanstrom, "Capsules and Nodes," p. 60.

${ }^{9}$ Gibson, Neuromancer, p. 52.

${ }^{10}$ Antonio Negri and Michael Hardt, Empire (Cambridge: Harvard University Press, 2000), p. 255.

${ }^{11}$ Ibid.

${ }^{12}$ Matteo Mandarini, "Introduction," Time for Revolution by Antonio Negri (New York: Continuum, 2003), p. 4.

${ }^{13}$ Gibson, Neuromancer, p. 259.

${ }^{14}$ Negri, Empire, p. 216.

${ }^{15}$ Ibid. 